\title{
CORPORATE SOCIAL RESPONSIBILITY: A PANACEA FOR CURBING YOUTH RESTIVENESS IN THE NIGER DELTA REGION OF NIGERIA
}

\author{
Stanfast, Suotonye Barnabas \\ Department of Management \\ Niger Delta University \\ Tel: +2348036716199 \\ E-mail: barnabasy2k@yahoo.com \\ \& \\ Carter, Cleopass Akpoafagha \\ Department of Management \\ Niger Delta University \\ Tel: +2349032222222 \\ E-mail: akpoafagha@gmail.com
}

\begin{abstract}
The issue of restiveness among the youths in the oil rich Niger Delta region of Nigeria has reached phenomenal levels. In recent times it has caused a great deal of concern to the entire country, foreign investors and other relevant stakeholders due to the region's obvious contributions in generating foreign earnings for the nation. Aggrieved by the degree of degradation of the environment which is directly linked to oil exploration and exploitation activities of oil and gas companies operating in the region, agitated youths have resorted to violence and other social vices as a show of their displeasure to the injustice, hardship, and underdevelopment meted on the area by these companies. Considering the diverse benefits of Corporate Social Responsibility (CSR) to both organizations and society; and its ability to create business and socio-economic value while sustaining a cordial and mutual relationship amongst stakeholders, this paper examined Corporate Social Responsibility as a panacea for curbing restiveness among youths of the Niger Delta region, and by extension the entire youths of Nigeria. Revelations from this paper show that if done strategically, CSR programs have the potentials of appealing to the morals of stakeholders, sustaining competitive advantage for the organizations, improving organizational efficiency, improving operations and products, developing good reputation, and ultimately curbing youth restiveness in the Niger Delta region of Nigeria.
\end{abstract}

Keywords: Corporate Social Responsibility, Niger Delta Region, Community Development, Youth Restiveness. 


\section{Introduction}

The origin of youth restiveness in the Niger Delta region of Nigeria is traceable to the London and Lagos Constitutional Conferences of 1957 and 1958 respectively, where the political leaders of the region led by Chief Harold Dappa Biriye demanded the creation of a state of their own. This demand for state creation was fueled by the agitations among the Niger Delta people for fairness, equity and fair play in the socio-political and economic composition of Nigeria.

Barely six years after its independence, Nigeria experienced its first rebellion led by Isaac Adaka Boro, a former police officer and former president of the students' union of the University of Nigeria, Nsukka precisely on February 23, 1966. Boro, who led the "Niger Delta Volunteer Force" declared part of the region as "The Niger Delta Peoples Republic" as a means to free the region from oppression, underdevelopment and neglect it had suffered. This was effectively the genesis of the revolt in the Niger Delta. Although the revolt which began effectively on February 23, 1966 was quelled within twelve days by the nation's armed forces (Boro, 1982), it provided the foundation for subsequent rebellions in the region.

Restiveness of youths in the Niger Delta re-emerged in 1990 with the presentation of the Ogoni Bill of Rights to the Federal Government of Nigeria (MOSOP, 1990; Saro-Wiwa, 1992; SaroWiwa, 1995; Hunt, 2006). The culmination of the Ogoni struggle was the gruesome execution of Ken Saro-Wiwa and eight others on trumped-up charges by the then Federal Military Government.

The greatest catalyst of the revolt can be attributed to the Kaiama Declaration of 1998 by Ijaw youths drawn from about six hundred communities representing more than thirty clans. This has been the opening of the floodgate of revolt; for, since then so many groups have emerged, the most significant being the Movement for the Emancipation of the Niger Delta (MEND). The Niger Delta Avengers (NDA), which emerged in March 2016, can be said to be the most prominent among the newest groups in the area (Ikorukpo, 2018).

Militancy in the Niger Delta has been a tool for unleashing terror and criminality on the polity. The strategies used by the Niger Delta militia groups include: abduction of foreign and local oil and gas workers, blow up and vandalization of critical national assets and illegal bunkering of petroleum products, kidnapping, armed robbery, and killing (Akani, 2019).

The impact of these criminal activities of the youths in the Niger Delta region has been quite overwhelming on the economy during its peak periods. For instance, in 2006 alone, the Federal Government of Nigeria reportedly lost above N500 billion on account of restiveness in the region (Okeke, 2008). The problem became worse in 2008, with an estimated US $\$ 6.3$ billion in petroleum stolen, and another US $\$ 28$ billion in oil deliberately not produced due to the reduction in crude oil production to the tune of 500,000 barrels per day (Ubhenim, 2016). 
The alarming rate of insecurity in the Niger Delta due to the criminal activities of the restive youths also made the economy unattractive to foreign investors and this has negatively impacted on the economy and the overall development of the country even as at today. Given this gloomy scenario, there is every need to stop the hemorrhaging of the economy before its total collapse. One sure way of ensuring that is through Corporate Social Responsibility (CSR) by local and international oil companies operating in the Niger Delta region of Nigeria.

Corporate Social Responsibility (CSR) programs can impact a wide spectrum of organizational issues that will produce improved outcomes at every level of operations if it considers the socioeconomic values and potentials of the program. It requires fair, equitable, ethical and legal treatment of all organizational stakeholders which include employees and the public as a whole (Stephenson, 2009). According to Lantos (2001), ethical and strategic CSR provides extraeconomic value to society and organization. O'Dwyer (2003) opined that businesses should endeavour to give back to society a considerable percentage of what has been received from society. They should have concern for human rights, social justice, and economic interests of societies by trying to empower the society in general through accountability and transparency of organizational operations. The questions that readily come to mind are whether modern day organizations consider these facts in their CSR programs. Do organizations embark on CSR programs for the benefit of society or for their own selfish interest? While some organizations embark on CSR programs for the actualization of their selfish goals, others do not even see any need for CSR as it is considered a source of financial leakages.

While some companies across the world have created a niche for themselves through CSR, others have completely ignored or refused to see any need for CSR and rather bring untold hardship to their host communities. Regrettably, that is the scenario in the Niger Delta region of Nigeria. The region which is the country's major source of revenue and foreign exchange earnings, plays host to multinational companies that engage in oil exploration and exploitation activities. These companies rather than better the living conditions of the citizenries in the area through CSR have brought untold hardship to the populace through their exploration activities. Aquatic lives and farmlands have deliberately been destroyed, and drinkable water polluted. The operations of these multinational oil companies have sparked up social unrest in the oil producing area with hostage taking, kidnapping of oil expatriates and other sundry crimes becoming the norm; a situation which has not only affected the bottom line of these multinationals but also adversely impacted on the foreign earnings of the Nigerian state. It is pertinent to note that in order to bring this situation under control, these multinationals need to realign their corporate social responsibility to reflect the interest of host communities. This forms the basis for this paper. This paper seeks to examine the import of corporate social responsibility as a panacea for curbing youth restiveness in the Niger Delta region of Nigeria. 


\section{Literature Review}

The term Corporate Social Responsibility (CSR) which started as social responsibility of businessmen is today described differently by scholars. Some scholars refer to it as sustainable development, global citizenship, corporate citizenship, etc. (McElhaney, 2009). Irrespective of the name, what is critical is that CSR programs over the past decades have proven to be a sound business strategy for maintaining competitive advantage and creating business and socioeconomic values. Because of this, companies that are strategic in their thinking and decisionmaking process, line their CSR activities with their business goals and core competencies. CSR programs should form an integral part of the core business objectives and core competencies of an organization for it to create business value and positive social change.

\section{Corporate Social Responsibility: An Overview}

Corporate social responsibility (CSR) as a concept may have existed before the 1950s though as social responsibility of businessmen. Its evolution is traceable to the 1950s and has become popular and quite pertinent to business development for more than six decades now. Carrol (1999) traced the modern era of CSR to the 1950s. The concept expanded in the 1960s, it became quite popular in the 70s and the 80s; and during the 90s it rose to become a strategic construct amongst business executives. Prior to 1950s, CSR was not popular in business literature until 1953 when Howard R. Bowen, in his published work "Social Responsibilities of the Businessman", wrote about the pertinence for businessmen to be conscious about their social responsibility to the generality of society. Though during that period CSR was generally referred to as Social Responsibility (SR). His works on SR gained wide acceptability to the point that nearly a decade later, the term SR had experienced significant growth with different scholars making contributions to the subject. Keith Davis was one of the pioneer contributors to the concept in 1960, when he argued that businessmen's actions and decisions should go beyond self-serving economic and technical interest of the organization but that social responsibilities of businessmen should determine their social power. That same year, William C. Frederick further contributed to the concept of SR when he argued that businessmen should and must utilize the economic resources of state/community for the development of the socio-political and economic welfare of the populace through production and distribution. By 1963, Joseph W. McGuire in his contribution to the advancement of CSR noted that businesses are distinct from its owners and therefore should show interest in the politics, social welfare, education, etc. of society as a whole. He advised that businesses should assume their place as citizens and act in a just way. In 1967, Clarence C. Walton in his publication titled "Corporate Social Responsibilities" further made popular the notion that business firms and business persons to contribute meaningfully to the advancement of society.

By the 70s, the concept of social responsibility had evolved into what is today known as Corporate Social Responsibility. Some contributors to the evolution in the 70s include Morrel Heald (1970); Harold Johnsons (1971); Committee for Economic Development in its 1971 
publication Social Responsibilities of Business Corporations; George Steiner (1971); Keith Davis (1973); Henry Eilbert and I. Robert Parker (1973); Eells and Walton (1974); Jules Backman (1975), and many others like Carrol (1999). All these contributors emphasized the need for businesses to consider issues beyond their internal setting but also putting in perspective the impact of external factors on the general performance of the company with a view to meeting the socio-economic needs of people while also striving to meet the traditional economic gains of the company.

In the $80 \mathrm{~s}$ and $90 \mathrm{~s}$, there were further arguments on the notion of CSR which also popularized the idea and gave it wider acceptability. Lately in 2011, supra national institutions like the European Union (EU) have added their voice to the argument and described CSR as "a concept whereby companies integrate social and environmental concerns in their business operations and in their interaction with the stakeholders on a voluntary basis".

The World Business Council for Sustainable Development (WBCSD) in 2006 described the concept as the commitment by an organization to act in an ethical manner and get involved in the economic advancement of society while improving the quality of life of the workers and their households as well as of the local community and society at large. This position agrees with $\mathrm{Dr}$ Michael Hopkins' position when he described CSR in September 2007 as a process that deals with treating the stakeholders of a business entity or institution in an ethical manner. He also noted that the wider aim of social responsibility is to create higher and higher standards of sustainable living, while preserving the profitability of the business or the integrity of the institution, for people both in and around these entities.

As at today, a sizeable number of writers have written on the concept explaining what it entails, how it can really be operationalized, its importance to business development, its long-term effect on organizational performance, customer loyalty, and capacity to promote mutual co-existence between organizations, host communities, and by extension the larger society. Presently, the term Corporate Social Responsibility is a household name in business parlance even though some organizations elect to call it other names as earlier stated in this paper.

\section{The Niger Delta}

The Niger Delta region of Nigeria is generally referred to as the "back bone" of the Nigerian state because it is the country's main source of foreign earnings. Prior to 1956, this region was only prominent as the hub of trans-Atlantic slave trade decades ago; but when crude oil was discovered in commercial quantity in 1956 at Oloibiri, Bayelsa State, and subsequent at Obagi in 1960 in Rivers State. Nigeria today is 90 percent reliant on the exploration of crude oil and this region plays host to oil multinationals that contribute about 90 percent of Nigeria's Gross Domestic Product (GDP) and National Income (NI). It is heart breaking to learn that despite the abundant crude oil deposits and the presence of these multinationals, the region is still the most underdeveloped in Nigeria (Snapps \& Hamilton, 2011). This region covers about 70,000 square 
kilometers of Nigeria's total landscape. Its vegetation is a mixture of swamp and rainforest. The region which lies in the southern geographical zone of Nigeria is between latitude $4^{\circ} 14^{\prime}$ and $5^{\circ}$ $33^{\prime}$ North, longitude $5^{\circ} 48^{\prime}$ and $7^{\circ} 4^{\prime}$ East and extends to the Atlantic coastline from Benin River west of River Niger to Bonny River east of River Niger (Rhuks, Lawrence, \& Okonmah, 2009).

This region has four different vegetations: the fresh water swamp, the salt water swamp, the coastal and sand beaches ridges, and the off-shore zone (Snapps \& Hamilton, 2011). It is popularly known for its marine resources from the Atlantic Ocean and also for crude oil and natural gas production. The major occupation of the populace is farming, fishing, and trading (George \& Kuye, 2012) with diverse ethnic groups and tribes within the region.

In the last two decades, the Niger Delta region of Nigeria has been characterized with violence, insecurity, and social unrest resulting from environmental pollution and degradation resulting from oil exploration activities of multinationals. The youths who thought that with the beginning of exploration activities by these oil majors' life will be better have experienced disappointment and neglect. These multinationals doing business in this part of the country through their operations have not only caused environmental degradation; there has been multiplicity of cases of oil spillages that have continued to bring untold hardship on the populace. Rather than create socio-economic value for the indigenes of the area through strategic corporate social responsibility, these multinational companies get involved in unethical practices resulting in communal crises leading to loss of innocent lives and valuable property (Snapps \& Hamilton, 2011). The repeated oil spillages witnessed in the area have adversely affected aquatic resources and the only source of survival and livelihood of the populace. These companies through their operations discharge toxic industrial materials into the ocean and rivers thus exposing the inhabitants to diverse communicable diseases that have increased mortality rate in the area (George \& Kuye, 2012). These companies have neglected and/or ignored the role of corporate social responsibility in creating business and socio-economic value for organizations and society at large. Rather than identify the social needs of the area and meet these needs through CSR programs, these oil companies have largely made the region worse than they met it. The Niger Delta region is today the most underdeveloped with the obvious absence of basic infrastructural and social amenities. The inhabitants of the area have been further impoverished because their means of livelihood is no more (Owualah \& Lawrence, 2008). This show of irresponsibility by these oil companies and the complete neglect of their role as change agents through CSR have left the agitated youths in this area with no other option than to take violence and other kinds of social unrest. As a means of ventilating their grievances, frustration, and discontentment for this injustice; young men in the region now engage in the disruption of industrial activities, violent demonstrations, hostage taking, vandalization of oil pipelines, militancy, etc. It is noteworthy that the actions of these youth have not only stalled oil production of these multinationals, it has affected their economic gains and the foreign earnings of the country thus making the government to run deficit budget for so many years now (Ubhenin \& Enabunene, 2011). 


\section{Corporate Social Responsibility and Youth Restiveness in Niger Delta Region of Nigeria}

A critical focus of corporate social responsibility is the need for organizations to act in a socially responsible manner (O'Dwyer, 2003). Organizations owe it a duty to be socially responsible to society that is, giving back to society what they have derived from the society. No organization can exist without a society. It follows therefore that there must exist a symbiotic and/or mutually beneficial relationship between companies and the society at large. Organizations through their activities should show concern for human rights and social justice.

According to Lantos (2001), CSR can be divided into ethical, altruistic, and strategic CSR. Ethical CSR is targeted at reducing the negative effects of organizations' actions on society, altruistic CSR is when organizations carry out social actions for the wellbeing of society without benefitting from such actions, and strategic CSR is carried out when management intends to also benefit from their action. McElhaney (2009) suggested that for CSR program to create business value and propel positive social change, it needs to be connected to the corporate strategy of the company. It should be factored into the company's core business objectives and core competencies.

The benefits of CSR to companies and the society at large cannot be over stated. However, as earlier noted only strategic CSR can be of benefit to both organization and society. Some benefits of an effective CSR to an organization include improved organizational reputation and branding, reduced operational cost, employee loyalty and commitment, recruitment and retention of talented workforce, competitive differentiation and fostering an enabling environment for markets penetration (McElhaney, 2009). It is noteworthy that for CSR programs to derive its full benefits, senior executives need to be fully engaged and show commitment to the program. The CSR program must reflect the core values of the company with its mission and vision in mind. This will not only create social or environmental value but also business value that has the potential of creating competitive edge for the organization. Such business value should include ability to create new products and revenue streams. CSR programs should be structured such that everyone buys into it. As a test of its potency and to encourage full participation by all internal stakeholders, the outcome of the program should be built into the performance appraisal system of the company with CSR performance metrics such as reputation improvements, market share gained, brand perception, increased sales, and positive social change. An important component in developing CSR strategy is the pertinence of effectively and clearly communicating the program intent and content to all relevant stakeholders. A well developed and clearly communicated CSR program will impact on all stakeholders (internal and external) alike.

Research has shown that economic self-interest is the principal factor motivating the recognition of corporate social responsibility by managers (O’Dwyer, 2003). Managers believe that for CSR program to be accepted, it must support economic goals. However, having a good understanding of what the society/stakeholders want and embarking on CSR that will meet these societal needs 
is pertinent for the success and acceptability of CSR practices; and positively impacting on the company's bottom line.

\section{Conclusion and Recommendations}

The issue of youth restiveness currently been witnessed in the Niger Delta region of Nigeria is occasioned by multinationals neglecting their CSR function to their host towns and villages. If these multinationals can consider CSR programs as an avenue to give back to society what they have gained from the society, CSR has the capacity to positively impact on organizational issues that will produce improved outcomes in various levels of operations and also create socioeconomic values for both the organization and its host communities. All that is required of these multinationals is fair, equitable, ethical, just and legal treatment of all organizational stakeholders which include employees and the public as a whole (Stephenson, 2009).

While embarking CSR programs, these multinationals should maintain ethical standards and avoid personal and professional conflict of interest. They should however carry out CSR programs within the ambit of the law by obeying all government rules and regulations. Their CSR programs should be focused on not only creating competitive advantage for the organization but also creating appropriate value for its customers and stakeholders as this will encourage patronage and involvement that will be converted into improved revenue and profits. Besides creating competitive advantage, CSR can be harnessed to maintain a positive relationship between and amongst organizations, customers, and the society at large. This should be done with right organizational resources and within the context of ethical business practices.

Oil companies operating in the Niger Delta region of Nigeria should develop CSR programs as part of their core operations and this should be integrated into their organizational culture and values. Their CSR programs should be done in a strategic manner with the support of leadership and management of the corporate headquarters. When this is done, it will no doubt appeal to the morals of stakeholders particularly the youths, sustain competitive advantage for the organizations, improve organizational efficiency, improve operations and products, develop good reputation, and ultimately curb youth restiveness in the area. 


\section{References}

Akani, N. K. (2019). Youth Restiveness in the Niger Delta, Criminality and Economic Development in Nigeria. Academic Journals.

Backman, J, (Ed). (1975). Social responsibility and accountability: New York: New York University Press.

Boro, I. J. A. (1982). The Twelve Day Revolution. Benin City, Nigeria: Umeh Publishers.

Carrol, A.B. (1999). Corporate social responsibility: Business and Society, 38(3), 268-295. Retrieved from the Walden Library using ABI/INFORM Complete.

Davis, K. (1973). The case for and against business assumption of social responsibilities. Academy of Management Journal, 16, 312-322.

Eells R. \& Walton C. (1974). Conceptual Foundations of Business, $3^{\text {rd }}$ Edition, Irwin, Burr Ridge, IL.

Eilbert, H. \& Parker, I.R. (1973). The current status of corporate social responsibility. Business Horizons, 16, 5-14.

Frederick, W. C. (1960). Corporation, be Good: The Story of Corporate Social Responsibility. Dog Ear Publishing.

George, O. J. \& Kuye, O. L. (2012). Corporate Social Irresponsibility (CSI) a Catalyst to the Niger Delta Crisis: The Case of Nigerian Oil Multinational Companies versus the Militants of Niger Delta Region of Nigeria. Journal of Management Research, 4(2), 111. Retrieved from ABI/INFORM Complete database.

Heald, M. (1970). The Social responsibilities of business: Company and community, 1900-1960. Cleveland, OH: Case Western Reserve University Press.

Hopkins, M. (2007). What is Corporate Social Responsibility all about? Journal of Public Affairs.

Ijaw Youth Council (1998). The Kaiama Declaration, Kaiama: IYC.

Johnson, H.L. (1991). Business in a contemporary society: Framework and issues. Belmont, CA: Wadsworth.

Keith, D. (1973). "The Case for and Against Business Assumption of Social Responsibility," Academy of Management Journal, 1, 312-322.

Lantos, G. P. (2001). The boundaries of strategic corporate social responsibility. The Journal of Consumer Marketing, 18(7), 595-630. Retrieved from ABI/INFORM Complete.

McElhaney, K. (2009). A strategic approach to corporate social responsibility: Leader to Leader. 52, 30-36. Retrieved from the Walden Library using the Business Source Complete database. 
McGuire, J.W. (1963). Business and Society, McGraw-Hill.

MOSOP, (1990). Ogoni Bill of Rights: Presented to the Government and People of Nigeria. 26 August, 1990.

O'Dwyer, B. (2003). Conceptions of corporate social responsibility: The nature of managerial capture. Accounting, Auditing \& Accountability Journal, 16(4), 523-557. Retrieved from the Walden Library using ABI/INFORM Complete.

Okeke, M. (2007). 'Government of Spend N71.7b on NDDC in 2008'. The Guardian, 20"th September 2007, p.80.

Owualah, S. I. \& Lawrence, O. O. (2008). Tackling youth restiveness in the Niger Delta region of Nigeria through entrepreneurship. Journal of Enterprising Communities. 2(2), 168179. Retrieved from ABI/INFORM Complete database.

Rhuks, T. A.; Lawrence, O. O. \& Okonmah, P. (2009). Forging peaceful Relationships between oil companies and host communities in Nigeria's Delta region: A stakeholder's perspective to corporate social responsibility. Journal of Enterprising Communities, 3(2), 205-216. Retrieved from ABI/INFORM Complete database.

Snapps, O. J. \& Hamilton, D. I. (2011). Youth Restiveness and Industrial Disruption in the Niger Delta. American Review of Political Economy. 9(1).

Social responsibilities of business corporations. A book by Committee for Economic Development. CED, 1971.

Stephenson, A. (2009). The Pursuit of CSR and Business Ethics Policies: Is it a source of competitive advantage for organizations? The Journal of American Academy of Business, 14(2), 251-262.

Steiner, G. A. (1971). Dimensions of corporate social responsibility. California Management Review, 17, 58.

Ubhenin, O. E. (2008). The Federal Government's Amnesty Programme in the Niger Delta: An Appraisal.

Ubhenin, O. E. \& Enabunene, S. (2011). Youth restiveness and Credible alternatives to Violence in Nigeria. Journal of Human Security, 7(1). 